\title{
Growth, physiology, and nutrient retranslocation in nitrogen-15 fertilized Quercus rubra seedlings
}

\author{
K. Francis SAlifu ${ }^{1}$, Kent G. Apostol ${ }^{1,2}$, Douglass F. JACobS ${ }^{1 *}$, M. Anisul Islam ${ }^{1}$ \\ ${ }^{1}$ Hardwood Tree Improvement and Regeneration Center, Department of Forestry and Natural Resources, Purdue University, \\ West Lafayette, IN 47907-2061, USA \\ ${ }^{2}$ Present Address: Department of Biological Sciences, Bethel University, 3900 Bethel Drive, St. Paul, MN 55112, USA
}

(Received 12 February 2007; accepted 19 April 2007)

\begin{abstract}
We evaluated gas exchange, chlorophyll index (CI) using SPAD-502 chlorophyll meter, and leaf nutritional responses in one-year-old northern red oak (Quercus rubra L.) container seedlings transplanted into control (unfertilized) or fertilized $\left(0.86 \mathrm{~g} \mathrm{~N}\right.$ plant $\left.{ }^{-1}\right)$ sand culture and grown in a greenhouse for 90 days. We labeled current nitrogen $(\mathrm{N})$ uptake with $\left({ }^{15} \mathrm{NH}_{4}\right)_{2} \mathrm{SO}_{4}$ and directly quantified proportional contributions of $\mathrm{N}$ derived from fertilizer $(N F)$ compared with retranslocation or $\mathrm{N}$ derived from plant $(N P)$ in leaf growth of red oak seedlings. $N F$ met a greater $\mathrm{N}$ demand in leaf growth of fertilized plants while unfertilized seedlings relied entirely on $N P$ for their leaf growth. Fertilization increased leaf dry mass by $67 \%$ and new stem dry mass by $253 \% 90$ days after transplanting compared to control seedlings. Specific leaf area (SLA) was not significantly altered but CI increased 90 days after transplanting. Higher leaf $\mathrm{N}$ concentration and content in fertilized compared with control seedlings was linked to greater chlorophyll concentrations in the former plants. The higher coefficient of determination $\left(r^{2}=0.72\right)$ noted between leaf $\mathrm{N}$ concentrations and CI suggests that the SPAD meter could be a useful tool for assessing leaf $\mathrm{N}$ status in northern red oak seedlings. Fertilized seedlings exhibited higher net assimilation, stomatal conductance, and transpiration rates compared with controls. Increased seedling growth in response to fertilization was related to maintenance of higher gas exchange and greater nutrient uptake, which could improve outplanting success.
\end{abstract}

fertilization / gas exchange / northern red oak / nitrogen / photosynthesis / retranslocation / SPAD meter

Résumé - Croissance, échanges gazeux et réponses nutritionnelles de jeunes semis de Quercus rubra soumis à une fertilisation par $\left({ }^{\mathbf{1 5}} \mathbf{N H}_{\mathbf{4}}\right)_{2} \mathbf{S O}_{4}$. Nous avons estimé les échanges gazeux foliaires, un index de teneurs en chlorophylles (IC) avec un chlorophylle-mètre SPAD-502 et les teneurs en nutriments dans les feuilles de jeunes plants de chêne rouge d'Amérique (Quercus rubra L.) âgés d'un an. Les plants ont été transplantés dans du substrat sableux non fertilisé (témoins) ou fertilisé avec $0.86 \mathrm{~g} \mathrm{~N}$ par plante, et cultivés pendant 90 jours sous serre. L'azote apporté par la fertilisation était marqué avec $\left({ }^{15} \mathrm{NH}_{4}\right)_{2} \mathrm{SO}_{4}$ et nous avons directement quantifié les contributions à la croissance foliaire de $\mathrm{N}$ apporté par la fertilisation $(N F)$ par rapport à celle de $\mathrm{N}$ remobilisé depuis les pools de réserve de la plante $(N P)$. $N F$ constituait la fraction la plus importante d'azote foliaire de plants fertilisés, alors que l'azote foliaire des plants non fertilisés était exclusivement constitué de $N P$. La fertilisation s'est traduite par une augmentation, par rapport aux plantes témoins, de $67 \%$ de la biomasse foliaire et de $253 \%$ de la biomasse de tiges nouvellement formées 90 jours après la transplantation. La surface spécifique des feuilles n'était pas affectée par la fertilisation alors que CI avait significativement augmenté. Des teneurs plus élevées en $\mathrm{N}$ foliaire en comparaison des témoins, étaient donc liées à des concentrations plus fortes en chlorophylles. Le coefficient de détermination élevé $\left(r^{2}=0.72\right)$ des relations entre concentration de $\mathrm{N}$ et CI montrent que le SPAD-502 pourrait être un instrument utile pour l'évaluation des teneurs en $\mathrm{N}$ dans des semis de chêne rouge. Les semis fertilisés présentaient également des niveaux d'assimilation nette de $\mathrm{CO}_{2}$, de conductance stomatique et de transpiration plus élevés que les plants témoins. La croissance plus forte des semis en réponse à la fertilisation était liée à des échanges gazeux plus actifs et une plus forte assimilation de nutriments, ce qui peut augmenter les chances de succès à la transplantation en forêt.

fertilisation / échanges gazeux / chêne rouge / azote / photosynthèse / retranslocation / SPAD mètre

\section{INTRODUCTION}

Inadequate nutrition has been identified as a limiting factor constraining early seedling survival and growth $[29,52]$. For example, low nitrogen $(\mathrm{N})$ availability has been noted to limit growth and establishment success of hardwood plantations in the eastern USA $[25,26]$. Susceptibility to nutrient stress can be alleviated by fertilization at outplanting $[5,26]$. Hence, there is increased interest to fertilize seedlings at outplanting as a means to accelerate plant growth and improve afforestation and (or) reforestation success $[4,24,26]$.

\footnotetext{
* Corresponding author: djacobs@purdue.edu
}

The plant can respond to nutrient deficiency by internal redistribution of $\mathrm{N}$ to support existing sink demands. Nitrogen retranslocation from old tissues is a key mechanism of $\mathrm{N}$ reuse to support new growth in evergreen conifers $[39,48]$. By labeling current uptake with the stable isotope ${ }^{15} \mathrm{~N}$, it is possible to directly quantify the proportional contribution of retranslocation or $\mathrm{N}$ derived from plant $(N P)$, which is differentiated from the isotopic ${ }^{15} \mathrm{~N}$ derived from applied fertilizer $(N F)$ in new growth of conifer seedlings $[35,39,48]$. The importance and proportional contributions of $N F$ compared with $N P$ in sinks of new growth has yet to be determined in temperate deciduous forest tree species such as northern red oak (Quercus rubra 
L.). Additionally, although retranslocation has been studied at the whole plant level, few studies have examined retranslocation response at the leaf level $[13,14]$.

Nitrogen is essential to photosynthetic metabolism and growth because of its role in the synthesis of chlorophyll and proteins such as ribulose-1, 5-biphosphate carboxylase (Rubisco), which is responsible for $\mathrm{CO}_{2}$ assimilation [32]. Although $\mathrm{N}$ fertilization has been shown to promote seedling growth in conifers $[19,21,44]$, there is little information on $\mathrm{N}$ use in hardwood afforestation plantings in the Central Hardwood Forest Region of the USA. Additionally, although some studies have examined physiological processes such as photosynthesis in response to fertilization of conifers $[23,28]$, fertilization studies involving hardwoods have generally reported only seedling biomass and nutrient dynamics [26]. Thus, initial physiological changes to help explain seedling growth responses following fertilization are not well characterized for hardwoods, especially at the leaf level.

More importantly, a need exists for diagnostic systems that can afford easy appraisal of plant $\mathrm{N}$ status to help design fertilizer prescriptions to enhance seedling survival and growth. Conventional wet-chemistry techniques exist for assessing plant $\mathrm{N}$ status, which involves destructive sampling of plant materials $[11,47]$. These techniques are relatively expensive and laborious and therefore, not suitable for rapid appraisal of plant $\mathrm{N}$ status throughout the growing season. The importance and utility of SPAD-502 chlorophyll meter for rapid and non-destructive appraisal of plant leaf $\mathrm{N}$ status has been demonstrated $[6,9]$. Strong correlations were noted between chlorophyll index (CI) values obtained from the SPAD meter with leaf chlorophyll and $\mathrm{N}$ concentrations in several herbaceous and woody plants [6,9]. The results of these studies suggest that the SPAD meter could serve as a useful alternative to conventional wet-chemistry techniques. Here, we extend the application of the SPAD meter to examine the relationship between SPAD readings and foliar N status obtained from conventional wet-chemistry techniques. To our knowledge, there is no published study that examined the utility of SPAD to assess foliar $\mathrm{N}$ in northern red oak.

In the present study, we evaluated growth, gas exchange, and leaf nutrient status of red oak seedlings in response to fertilization under greenhouse conditions for 90 days. We labeled current uptake with $\left({ }^{15} \mathrm{NH}_{4}\right)_{2} \mathrm{SO}_{4}$, which enabled direct quantification of $N F$ compared with $N P$ and their distribution in leaf growth of red oak seedlings. We tested the hypothesis that (1) fertilization increases photosynthetic rates and nutrient uptake in fertilized compared with unfertilized seedlings, and these responses partly explain the greater growth of the former plants, (2) a greater proportion of $N F$ will meet the $\mathrm{N}$ demand in leaf growth of fertilized seedlings while unfertilized plants will rely entirely on $N P$ for seasonal leaf growth and, (3) a strong relationship exists between SPAD meter readings with $\mathrm{N}$ determined by conventional wet-chemistry indices inferring good predictability of leaf $\mathrm{N}$ status with SPAD as noted elsewhere $[6,56]$. We focused on $\mathrm{N}$ because it is the nutrient element most commonly limiting plant growth and because its role in controlling plant growth and metabolism is well understood $[7,15]$. Northern red oak was examined in this study because of its importance and frequent use in reforesta- tion and (or) afforestation plantings in the Central Hardwood Forest Region, USA [25].

\section{MATERIALS AND METHODS}

\subsection{Plant material and treatments}

Northern red oak acorns, collected on the Purdue University campus, West Lafayette, IN, USA ( $\left.40^{\circ} 25^{\prime} \mathrm{N}, 86^{\circ} 55^{\prime} \mathrm{W}\right)$, were germinated and seedlings grown for 18 weeks in 2.8-1 Treepots ${ }^{\mathrm{TM}}$ (Stuewe and Sons, Corvallis, OR, USA) filled with Scotts Metro-Mix ${ }^{\circledR} 560$ growing medium (The Scotts Company, Marysville, OH, USA). The medium is comprised of 35 to $54 \%$ composted pine bark, 20 to $30 \%$ processed coconut coir pith, 10 to $20 \%$ sphagnum peat moss, 5 to $15 \%$ processed bark ash, and 5 to $15 \%$ horticultural perlite. Seedlings received a total of $100 \mathrm{mg} \mathrm{N}$ plant $^{-1}$, applied exponentially over the 18-week growing season as detailed in Salifu and Jacobs [47]. Seedlings were grown in the greenhouse at the Department of Horticulture and Landscape Architecture Plant Growth Facility at Purdue University, West Lafayette IN, USA ( $\left.40^{\circ} 25^{\prime} \mathrm{N}, 86^{\circ} 55^{\prime} \mathrm{W}\right)$. The greenhouse was set for $24 / 20{ }^{\circ} \mathrm{C}$ day/night air temperatures, relative humidity of 60 to $70 \%$, and 16-h photoperiod with photosynthetic photon flux density of 350 to $400 \mu \mathrm{mol} \mathrm{m}{ }^{-2} \mathrm{~s}^{-1}$ measured at seedling top height. After 18 weeks in the greenhouse, seedlings were hardened-off for over winter storage and stored at $-2{ }^{\circ} \mathrm{C}$ for about six months prior to the start of the current experiment.

\subsection{Greenhouse transplanting trial}

This study was conducted in the same greenhouse as described above. Before being transplanted into 6.2-1 Treepots (Stuewe and Sons, Corvallis, OR, USA) filled with sand, we gently washed seedling root systems free of medium. This was done to remove any residual fertilizer remaining in the medium from the previous growing season. We used stable isotope ${ }^{15} \mathrm{~N}$ as our nitrogen source for the fertilized treatment, supplied with irrigation as $\left({ }^{15} \mathrm{NH}_{4}\right)_{2} \mathrm{SO}_{4}$ enriched to 5 atoms $\%{ }^{15} \mathrm{~N}$ (34-0-0, ISOTEC Inc., USA). Transplanted seedlings were either unfertilized (controls; received $0 \mathrm{~kg} \mathrm{~N} \mathrm{ha}^{-1}$ ) or fertilized (at $200 \mathrm{~kg} \mathrm{~N} \mathrm{ha}^{-1}$ ) equivalent to $0.86 \mathrm{~g} \mathrm{~N}$ plant $^{-1}$ based on the weight of sand in our pots in relation to silvicultural prescriptions under field conditions [3,48]. Chelated (EDTA 55\%) micro-elements were supplied in the irrigation at the rate of $0.08 \mathrm{~g} \mathrm{~L}^{-1}$ and phosphorus (P) supplemented by $\mathrm{KH}_{2} \mathrm{P}_{2} \mathrm{O}_{5}$ (0-52-34, Plant Products Co Ltd., Brampton, Ontario, Canada) at the rate of $30 \mathrm{~kg} \mathrm{P} \mathrm{ha}^{-1}$ to avert deficiency of other nutrients. Seedlings flushed one week after planting at which time fertilization commenced. Three split applications were conducted at 7,14 , and 28 days after planting to improve uptake efficiency. Pots were irrigated to container capacity at each fertigation $[46,55]$. A group of two crates represented an experimental unit. To keep pots upright, we fitted four pots or seedlings into each crate. The control and fertilized treatments were then randomly assigned to a group of two crates and arranged in a randomized complete block design in three replicate blocks. The blocks were placed on raised benches and were rotated bi-weekly to minimize edge effects. At transplanting, 2 plants were sampled per replicate and 3 replicates were evaluated (6 seedlings) per treatment to characterize initial status. 


\subsection{Measurements}

Leaf gas exchange measurements were conducted 60 and 90 days after planting. On days 60 and 90 after transplanting, we randomly selected 6 seedlings from each treatment $(2$ from each replicate for leaf gas exchange, biomass, chlorophyll index (CI), specific leaf area (SLA), and chemical analysis. Net photosynthesis $(A)$, stomatal conductance $\left(g_{\mathrm{s}}\right)$, intercellular $\mathrm{CO}_{2}$ concentration $\left(C_{i}\right)$, and transpiration $(E)$ were measured with LI-6400 portable infrared gas analyzer equipped with a red LED light source and a $\mathrm{CO}_{2}$ mixer control unit (LI-COR Inc., NE, USA) on the 6 seedlings from each treatment. Measurements were taken on the second fully formed leaf moving basipetally from the terminal point of the second flush. Measurements occurred continuously from 09:00 to 16:00 h for day 60 taken at three time intervals (9:00, 12:00, and 16:00) and from 09:00 to 18:00 h for day 90 at five time intervals (9:00, 12:00, 14:00, 16:00, and 18:00). External light, provided by LED red light source (LI6400-02) built into the top of the leaf chamber, was set to light intensity present in the greenhouse during each measurement period to ensure uniform light conditions. $\mathrm{CO}_{2}$ was controlled with the $\mathrm{LI}-6400 \mathrm{CO}_{2}$ injection system. Relative humidity was maintained at 55 to $65 \%$, resulting in a leaf-to-air vapor pressure deficit ranging from 1.25 to $1.75 \mathrm{kPa}$. Leaf temperature was maintained at ambient conditions $\left(28\right.$ to $\left.30{ }^{\circ} \mathrm{C}\right)$.

\subsection{Plant sampling and chemical analyses}

Immediately following gas exchange measurements, seedlings were harvested and plants were partitioned into leaves, new stem, old stem, and roots, composited by replication, and oven-dried at $70{ }^{\circ} \mathrm{C}$ for $72 \mathrm{~h}$. Chlorophyll index was measured using SPAD-502 chlorophyll meter (Minolta, Ramsey, NJ, USA) at midday on fully expanded leaves halfway from the leaf base to the tip and halfway from the midrib to the leaf margin on the same six seedlings used for leaf gas exchange. Two randomly selected leaves were harvested for determination of SLA by measuring the area and then oven drying at $70{ }^{\circ} \mathrm{C}$ for at least $72 \mathrm{~h}(n=6)$. Oven-dried leaves were ground to pass through a $2-\mathrm{mm}$ sieve and sent to A\&L Great Lakes Laboratories (Fort Wayne, IN, USA) for chemical analyses. Total N was determined by combustion "Dumas" procedure (Association of Official Analytical Chemist (AOAC) 968.06) using a LECO nitrogen analyzer (LECO Corporation, St. Joseph, MI, USA). Additionally, samples were digested in nitric + perchloric acids (AOAC 935.13), and $\mathrm{P}$ and $\mathrm{K}$ determined using inductively coupled argon plasma (ICAP) analysis (AOAC 985.01). Total $\mathrm{N}$ and ${ }^{15} \mathrm{~N}$ were analyzed for plant components (leaves, new stem, old stem, and roots) using a Stable Isotope Finnigan Delta C, Mass Spectrometer (Thermo-Electron; Bremen, Germany) coupled to a Micro-Dumas Elemental analyzer (NA1500 CHN; Carlo Erba Instruments, Milan, Italy) at the stable Isotope Laboratory located at the University of Georgia, Athens, GA, USA.

\subsection{Calculations and statistical analysis}

Current ${ }^{15} \mathrm{~N}$ uptake from the soil or $\mathrm{N}$ derived from fertilizer $(N F)$ was computed from Equation (1) and retranslocation or unlabelled $\mathrm{N}$ derived from plant $(N P)$ was calculated from Equation $(2)[35,45,48]$.

$$
N F=T N\left[\frac{(A-B)}{(C-B)}\right]
$$

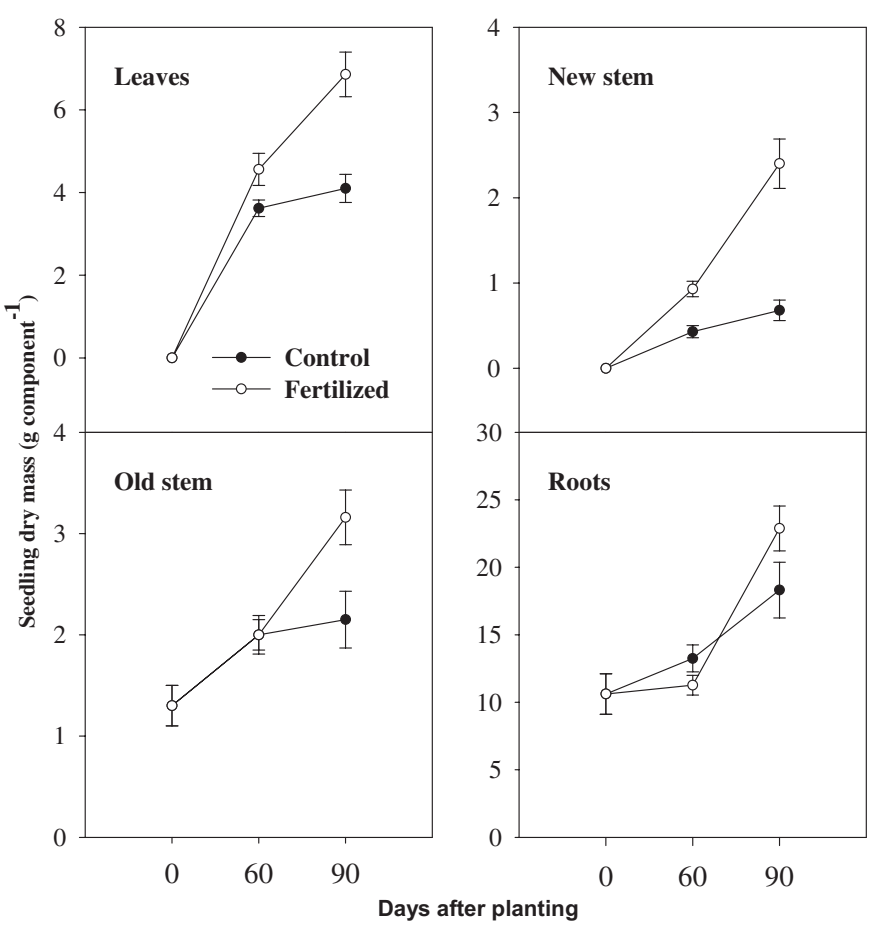

Figure 1. Component dry mass of fertilized and unfertilized (control) northern red oak seedlings grown in sand culture for 90 days under greenhouse conditions. Each data point represents least squares means $\pm \operatorname{SE}(n=6)$.

where:

$T N=$ total $\mathrm{N}$ content $(\mathrm{mg})$ of plant component estimated as concentration multiplied by component dry mass.

$A=$ at $\%{ }^{15} \mathrm{~N}$ in fertilized plant tissues, $B=$ at. $\%{ }^{15} \mathrm{~N}$ in natural standard (0.366) or control, and $C=$ at $\%{ }^{15} \mathrm{~N}$ in fertilizer.

$$
N P=T N-N F \text {. }
$$

Growth and physiological data were subjected to analysis of variance (ANOVA) using SAS general linear model (SAS Institute Inc., Cary, NC). Tests for normality and constant variance were performed to ensure the validity of the assumptions of ANOVA were met and no transformations were necessary. Fisher's Protected Least Significant Difference test was used to separate significant treatment means at $\alpha=0.05$. Gas exchange variables $\left(g_{\mathrm{s}}, A, E\right.$, and $\left.C_{i}\right)$ were analyzed for each measurement period. The data presented in the figures are the least squares means of 6 seedlings from each treatment $(n=6)$.

\section{RESULTS}

\subsection{Growth responses}

Component dry masses of unfertilized seedlings were lower compared with fertilized plants (Fig. 1). Unfertilized plants were also visually chlorotic at the final harvest. Greater differences in seedling growth were observed at day 90. For example, new stem growth increased $116 \%$ at day 60 and $253 \%$ at day 90 in fertilized compared with unfertilized plants. Similarly, fertilization increased leaf dry mass by $26 \%$ at day 60 

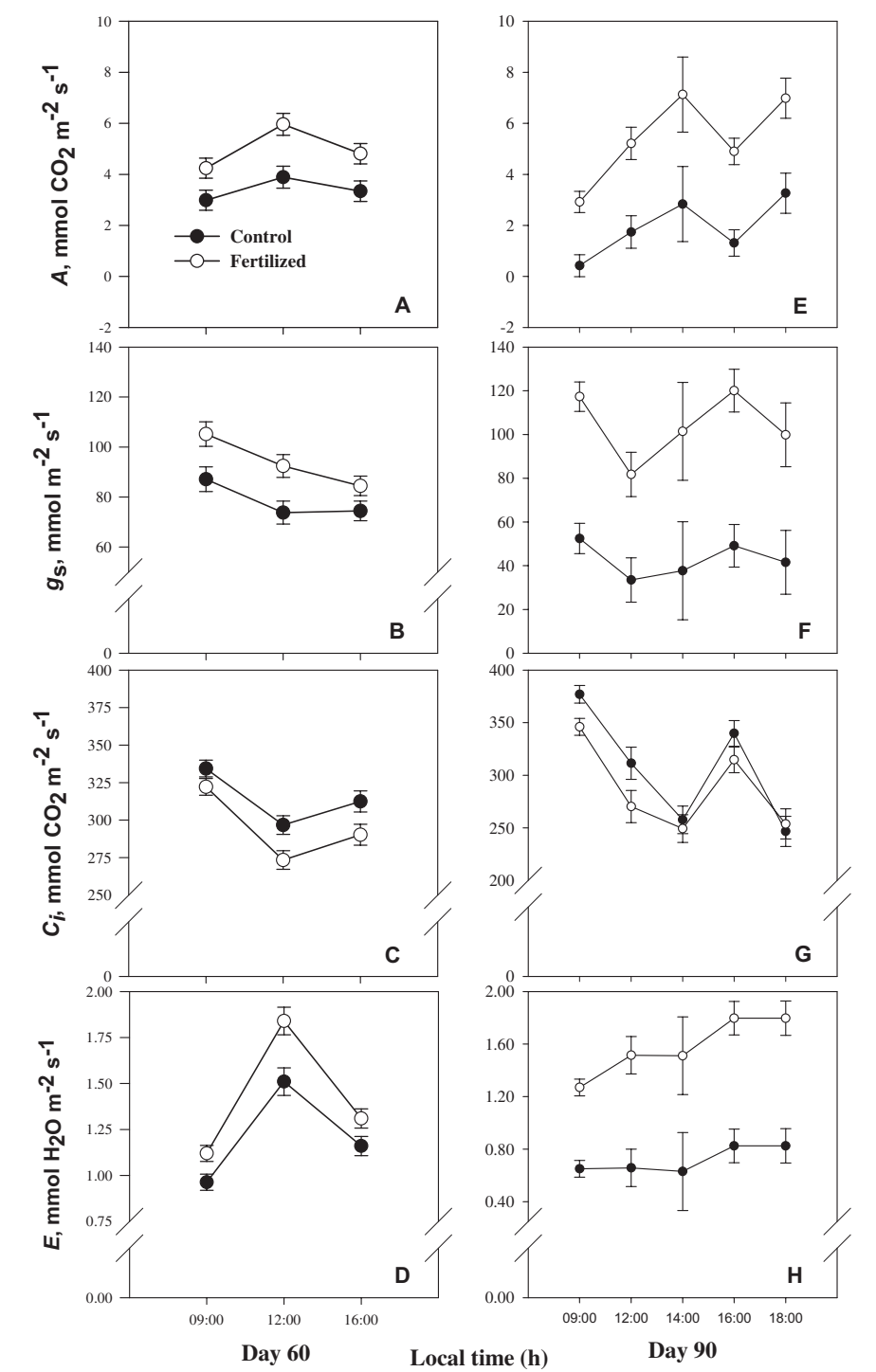

Figure 2. Diurnal responses (A and $\mathrm{E}$ ) net photosynthesis, $\mathrm{A}$; (B and F) stomatal conductance, $g_{\mathrm{s}} ; \mathrm{C}$, and $\mathrm{G}$ ) intercellular $\mathrm{CO}_{2}$ concentration, $C_{i}$; and $(\mathrm{D}$ and $\mathrm{H})$ transpiration, $E$ of fertilized and unfertilized (control) northern red oak seedlings grown in sand culture under greenhouse conditions and sampled 60 (left) and 90 (right) days after transplanting. Each data point represents least squares means $\pm \mathrm{SE}$ $(n=6)$.

and by $67 \% 90$ days after transplanting (Fig. 1). There was greater allocation of plant dry mass to roots (70 to $78 \%$ ) than shoots (Fig. 1). Root dry mass was similar between control and fertilized seedlings at day 60, but became significantly different $(P=0.05)$ by day 90 .

\subsection{Leaf physiology}

Net assimilation, $g_{\mathrm{s}}$, and $E$ rates were significantly lower $(P=0.05)$ in control compared with fertilized seedlings (Fig. 2). However, fertilized plants generally had lower $C_{i}$ val-
Table I. Leaf nutrient concentration and content of fertilized or unfertilized (control) northern red oak seedlings grown in sand culture for 60 and 90 days under greenhouse conditions. Values represent least squares means $\pm \mathrm{SE}(n=6)$. Except for $\mathrm{K}$, treatment means were significantly different at $P<0.05$.

\begin{tabular}{|c|c|c|c|c|c|c|}
\hline \multirow{3}{*}{ Day/treatment } & \multicolumn{6}{|c|}{ Leaf nutrient } \\
\hline & \multicolumn{3}{|c|}{ Concentration $\left(\mathrm{g} \mathrm{kg}^{-1}\right.$ leaf $\left.^{-1}\right)$} & \multicolumn{3}{|c|}{ Content (mg leaf $\left.{ }^{-1}\right)$} \\
\hline & $\mathrm{N}$ & $\mathrm{P}$ & $\mathrm{K}$ & $\mathrm{N}$ & $\mathrm{P}$ & $\mathrm{K}$ \\
\hline \multicolumn{7}{|l|}{60} \\
\hline Con & $\begin{array}{l}11.17 \\
(0.61)\end{array}$ & $\begin{array}{c}0.75 \\
(0.03)\end{array}$ & $\begin{array}{c}7.22 \\
(0.38)\end{array}$ & $\begin{array}{l}15.36 \\
(2.16)\end{array}$ & $\begin{array}{c}0.98 \\
(0.12)\end{array}$ & $\begin{array}{c}9.32 \\
(0.90)\end{array}$ \\
\hline Ferti & $\begin{array}{l}21.00 \\
(0.66)\end{array}$ & $\begin{array}{c}0.96 \\
(0.03)\end{array}$ & $\begin{array}{c}7.02 \\
(0.38)\end{array}$ & $\begin{array}{l}24.35 \\
(2.33)\end{array}$ & $\begin{array}{c}1.13 \\
(0.12)\end{array}$ & $\begin{array}{c}8.22 \\
(0.90)\end{array}$ \\
\hline 90 & & & & & & \\
\hline Control & $\begin{array}{l}10.00 \\
(0.51)\end{array}$ & $\begin{array}{c}0.55 \\
(0.03)\end{array}$ & $\begin{array}{c}8.59 \\
(0.57)\end{array}$ & $\begin{array}{l}14.13 \\
(1.93)\end{array}$ & $\begin{array}{c}0.79 \\
(0.10)\end{array}$ & $\begin{array}{l}12.18 \\
(1.00)\end{array}$ \\
\hline Fertilized & $\begin{array}{l}20.20 \\
(0.49)\end{array}$ & $\begin{array}{c}0.84 \\
(0.03)\end{array}$ & $\begin{array}{c}8.72 \\
(0.56)\end{array}$ & $\begin{array}{l}25.92 \\
(1.87)\end{array}$ & $\begin{array}{c}1.07 \\
(0.09)\end{array}$ & $\begin{array}{l}10.75 \\
(0.97)\end{array}$ \\
\hline
\end{tabular}

ues than controls (Figs. $2 \mathrm{C}$ and $2 \mathrm{G}$ ). At day $60, A$ reached a peak of $3.89 \mu \mathrm{mol} \mathrm{CO} \mathrm{Cm}^{-2} \mathrm{~s}^{-1}$ in control seedlings and $5.86 \mu \mathrm{mol} \mathrm{CO} \mathrm{C} \mathrm{m}^{-2} \mathrm{~s}^{-1}$ in fertilized plants (Fig. 2A). A similar trend was observed in $E$ with $1.51 \mathrm{mmol} \mathrm{H}_{2} \mathrm{O} \mathrm{m}^{-2} \mathrm{~s}^{-1}$ in controls compared with $1.84 \mathrm{mmol} \mathrm{H}_{2} \mathrm{O} \mathrm{m}^{-2} \mathrm{~s}^{-1}$ in fertilized plants (Fig. 2D). $C_{i}$ values were high in the morning, declined during midday, then increased in the afternoon (Fig. 2C). $g_{\mathrm{s}}$ was high in the morning but decreased over time (Fig. 2B). Greater differences in $A, g_{\mathrm{s}}$, and $E$ between control and fertilized seedlings were observed at 90 days after transplanting with unfertilized plants exhibiting lower values (Fig. 2, right). Maximum $g_{\mathrm{s}}$ occurred in the morning, decreased at midday followed by another peak at 16:00, then decreased at 18:00 (Fig. 2F). $E$ values increased steadily over time reaching maximum values at 16:00 and 18:00 (Fig. 2H).

\subsection{Leaf nutritional responses}

Our primary focus was on leaves because these tissues are generally the most sensitive indicators of plant nutrient status and response to treatments [20,30,54]. Leaf N concentrations in control seedlings at days 60 and 90 were 37 and $46 \%$ lower $(P=0.0001)$ compared with fertilized seedlings (Tab. I). Nutrient contents and concentrations were significantly lower in control compared with fertilized seedlings with the exception of $\mathrm{K}$, which was not significantly altered $(P=0.731$, day 60 and $P=0.978$, day 90 ) (Tab. I). N uptake $(N F)$ and retranslocation $(N P)$ increased over time (Tab. II). For example, retranslocation ranged from 30 to $42 \%$ by day 60 and from 37 to $70 \% 90$ days after transplanting (Tab. II). Hundred percent of the $\mathrm{N}$ demand for leaf growth in unfertilized seedlings was met by NP. Retranslocation accounted for about $32 \%$ of the $\mathrm{N}$ demand in leaf growth of fertilized seedlings and $68 \%$ was met by $N F$ (Tab. II). Fertilized seedlings had $25 \%$ higher CI values compared with the control plants (Fig. 3A). No significant difference in SLA was observed between the control and 
Table II. Mean (SE) of current uptake represented by N derived from fertilizer $(N F)$ or retranslocation indicated by $\mathrm{N}$ derived from plant $(N P)$ expressed as a percentage of total $\mathrm{N}$ demand in leaf growth of fertilized and unfertilized (control) red oak seedlings grown in sand culture under greenhouse conditions and sampled at 60 and 90 days after transplanting. Treatment means were significantly different at $P<0.05$.

\begin{tabular}{lccccc}
\hline \multirow{2}{*}{ Sampled } & \multicolumn{5}{c}{ Plant leaf N } \\
\cline { 2 - 6 } & $\begin{array}{c}\text { Total } \\
(\mathrm{mg})\end{array}$ & $\begin{array}{c}N F \\
(\mathrm{mg})\end{array}$ & $\begin{array}{c}N F \\
\text { \% of total }\end{array}$ & $\begin{array}{c}N P \\
(\mathrm{mg})\end{array}$ & $\begin{array}{c}N P \\
\text { \% of total }\end{array}$ \\
\hline 60 & & & & & \\
Control & 42.19 & 0.00 & 0.00 & 42.19 & 100.00 \\
& $(2.42)$ & $(0.00)$ & $(0.00)$ & $(2.42)$ & $(0.00)$ \\
Fertilized & 99.47 & 68.85 & 67.77 & 30.62 & 32.23 \\
& $(19.08)$ & $(16.74)$ & $(3.86)$ & $(2.84)$ & $(3.86)$ \\
90 & & & & & \\
Control & 69.95 & 0.00 & 0.00 & 69.95 & 100.00 \\
& $(18.63)$ & $(0.00)$ & $(0.00)$ & $(18.63)$ & $(0.00)$ \\
Fertilized & 126.22 & 89.14 & 68.73 & 37.08 & 31.27 \\
& $(34.66)$ & $(29.39)$ & $(3.52)$ & $(5.32)$ & $(3.52)$ \\
\hline
\end{tabular}

fertilized seedlings (Fig. 3B). There was a significant linear relationship $\left(r^{2}=0.72, P \leqslant 0.001\right)$ between leaf $\mathrm{N}$ concentrations and CI (Fig. 4).

\section{DISCUSSION}

\subsection{Growth and retranslocation response}

High photosynthetic rates are associated with increased seedling growth and $\mathrm{N}$ allocation to foliage [12, 17,41]. Thus, increased biomass in seedlings following fertilization (Fig. 1) may be due to enhanced net photosynthetic rates in response to high $\mathrm{N}$ availability (Fig. 2A and 2E, Tab. I). Fertilization influenced not only total plant dry mass, but also altered partitioning of seedling dry matter (Fig. 1). More allocation of dry mass to roots in controls than in fertilized seedlings at day 60 reflects a classic plant response to nutrient deficiency $[8,15]$.

Retranslocation from old shoots [49] and (or) from roots $[22,38]$ has been shown to contribute significant amounts of nutrients to support growth of newly planted seedlings until roots establish and can exploit soil resources or until plants can utilize photosynthetic products in growth [33]. Total reliance on internal $\mathrm{N}$ cycling for leaf growth observed in unfertilized red oak seedlings (Tab. II) affirms the importance of retranslocation to meet $\mathrm{N}$ demands in newly established seedlings concurring with results noted for conifer seedlings [48]. Higher N retranslocation in control compared with fertilized seedlings may indicate increased nutrient use efficiency to sustain nutritional demands for leaf growth. Similar results were reported for several Mediterranean Quercus species grown on nutrientpoor soils [43]. Although retranslocation of $\mathrm{N}$ to leaf growth appears to be an important mechanism of $\mathrm{N}$ reuse in northern red oak seedlings (Tab. II), $N F$ also enhanced seedling growth.

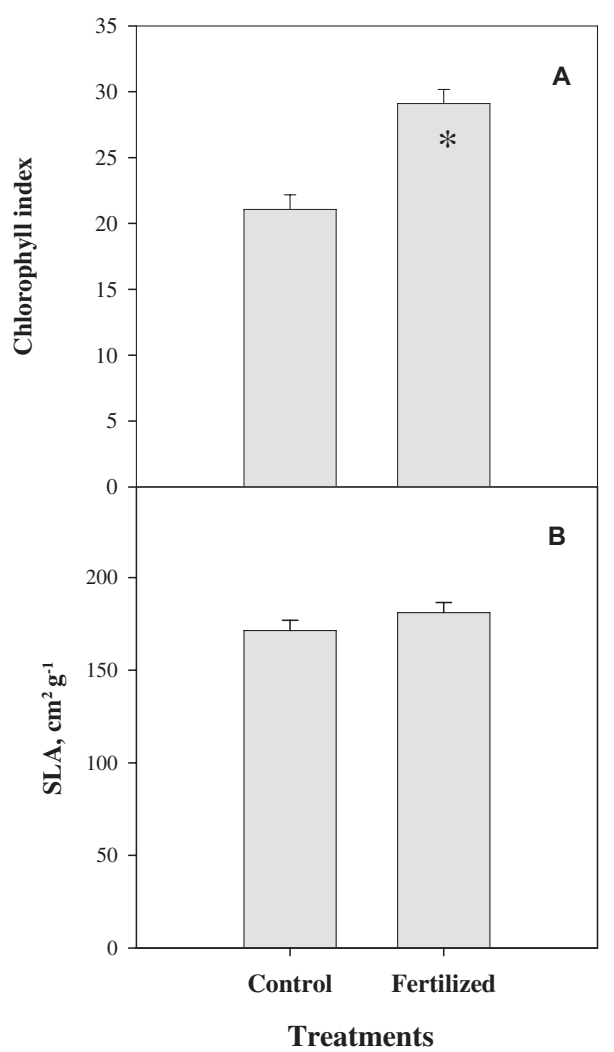

Figure 3. Chlorophyll index (A) and specific leaf area (B) of fertilized and unfertilized (control) northern red oak seedlings grown in sand culture under greenhouse conditions and sampled 90 days after transplanting. Least squares means $\pm \mathrm{SE}(n=6)$ are shown. $*$ Indicates a significant difference from the control at $\alpha=0.05$.

\subsection{Leaf physiology and nutritional responses}

The foliage is the site of photosynthetic activity and is therefore a sensitive indicator of plant nutritional status [20, $30,54]$. Nitrogen deficiency often inhibits plant productivity $[31,41]$ by reducing number of leaves, leaf area, and leaf $\mathrm{N}$ content [40], ultimately reducing maximum rates of photosynthesis [36]. Photosynthesis is reduced by $\mathrm{N}$ deficiency through its effects on chlorophyll synthesis and activity of photosynthetic enzymes $[17,51]$. Thus, a decrease in leaf $\mathrm{N}$ concentration could partly explain the observed chlorosis and lower $C I$ (SPAD readings) in unfertilized plants (Fig. 3A). The significant positive correlation observed between leaf $\mathrm{N}$ concentrations and chlorophyll index in northern red oak (Fig. 4) concurs with results of other studies with hardwoods $[6,56]$. In the present study, $C I$ could explain $72 \%$ of the variation in red oak leaf $\mathrm{N}$ concentrations. A similar strong linear relationship was also reported between SPAD reading, leaf $\mathrm{N}$ concentration, and photosynthetic capacity in aspen (Populus tremuloides Michx.) [11]. This suggests that the SPAD meter holds promise for rapid and non-destructive assessment of foliar N, which can help to effectively monitor seedling nutritional status. 


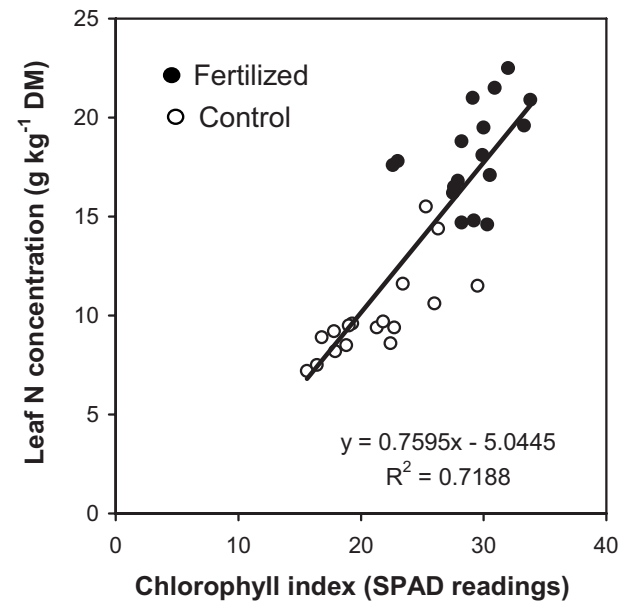

Figure 4. Relationship between leaf $\mathrm{N}$ concentrations and chlorophyll index in fertilized and unfertilized (control) northern red oak seedlings grown in sand culture under greenhouse conditions and sampled 90 days after transplanting.

Leaf size coupled with leaf $\mathrm{N}$ may regulate biomass productivity through its influence on light interception [27,34] and maximum rates of photosynthesis [37,50]. Higher leaf $\mathrm{N}$ and total plant biomass in fertilized seedlings confirms these observations. Several studies have shown that canopy SLA is closely related to canopy leaf $\mathrm{N}$ content and photosynthetic capacity [42]. In the present study, however, fertilization increased SLA by $6 \%$ in fertilized seedlings compared to controls, but this increase was not statistically significant (Fig. 3B).

While the lower $A$ rates in control seedlings could be attributed to lack of chlorophyll synthesis and activity of photosynthetic enzymes [17,51], a reduction in $g_{\mathrm{s}}$ in the presence of environmental stresses is often linked to decline in root water flow and root growth $[1,2,10]$. Although we did not measure root water flow in the present study, we observed decreased $g_{\mathrm{s}}, E$ rates, and less root growth in control seedlings (Figs. 1 and 2). A decline in root water uptake due to inhibition of water-channel mediated flow has also been attributed to nutrient deficiency $[10,16]$. It is plausible that lower nutrient concentrations observed in the leaves of control seedlings in this study could, in part, be due to lack of substrate nutrient level and its resultant adverse effects on root conductance. We speculate that leaf $\mathrm{N}$ concentration was not the only factor contributing to the greater effects on growth responses between unfertilized and fertilized seedlings. Freeden et al. [18] suggested that the photosynthetic process is down-regulated under conditions of $\mathrm{N}$ limitation. In our study, the observed decline in $g_{\mathrm{s}}$ in unfertilized seedlings resulted in reduced $\mathrm{CO}_{2}$ assimilation rates. It is plausible that the lower chlorophyll concentrations in unfertilized seedlings may have limited $A$, as chlorophyll is an important light absorbing pigment that drives photosynthesis [53].

\section{CONCLUSIONS}

Fertilization enhanced growth and chlorophyll concentrations in northern red oak seedlings. Higher $A, g_{\mathrm{s}}, E$, and increased leaf $\mathrm{N}$ concentration were noted in fertilized compared with unfertilized seedlings. Unfertilized plants relied entirely on $N P$ for leaf growth. A greater proportion of the $\mathrm{N}$ demand for leaf growth of fertilized seedlings was met by $N F(68 \%)$ compared with about $32 \%$ met by NP. A strong and positive linear relationship was found between SPAD readings and foliar $\mathrm{N}$; this suggests that the SPAD meter could serve as a rapid, non-destructive tool for inexpensive diagnosis of foliar $\mathrm{N}$ status for effective fertilizer recommendations in northern red oak seedlings. We propose that increased growth in fertilized compared with unfertilized seedlings was associated with improved gas exchange regulation, which enhanced nutrient acquisition with potential to promote seedling transplanting success.

Acknowledgements: This research was financially supported by a van Eck Post-Doctoral Research Scholarship, USDA Forest Service State and Private Forestry, and Purdue University. B. Wilson and A. Davis donated acorns for this study. C. Howard, C. Mahara, J. Ross, and M. Spalding assisted with processing of samples or greenhouse work. Assistance with maintenance of plants at the Purdue University Horticulture and Landscape Architecture Plant Growth Facility by Rob Eddy and his staff is acknowledged. We also thank Thomas $R$. Maddox and the staff of The Stable Isotope Laboratory at the Institute of Ecology located at the University of Georgia, Athens GA, USA for conducting total $\mathrm{N}$ and ${ }^{15} \mathrm{~N}$ analyses of plant samples. A\&L Great Lakes Laboratories Fort Wayne IN, USA conducted chemical analyses of leaf samples. We thank the Associate Editor and two anonymous reviewers for efforts expended in appraising our paper.

\section{REFERENCES}

[1] Apostol K.G., Zwiazek J.J., Hypoxia affects root sodium and chloride concentrations and alters water conductance in salt-treated jack pine (Pinus banksiana) seedlings, Trees 17 (2003) 251-257.

[2] Bauerle W.L., Wang G.G., Bowden J.D., Hong C.M., An analysis of ecophysiological responses to drought in American chestnut, Ann. For. Sci. 63 (2006) 833-842.

[3] Brady N.C., Weil R.R., The nature and properties of soils, 13th ed, Prentice Hall, New Jersey, 2002.

[4] Brockley R.P., The effects of fertilization on early growth of planted seedlings - a problem analysis, Forestry Canada, Ottawa Ont. For. Resour. Dev. Agree. Re 0835-0752:011, Victoria, British Columbia, 1988, pp. 16

[5] Burdett A.N., Herring L.J., Thompson C.F., Early growth of planted spruce, Can. J. For. Res. 14 (1984) 644-651.

[6] Chang S.X., Robinson D.J., Nondestructive and rapid estimation of hardwood foliar nitrogen status using the SPAD-502 chlorophyll meter, For. Ecol. Manage. 181 (2003) 331-338.

[7] Chapin F.S. III., The mineral nutrition of wild plants, Ann. Rev. Ecol. Syst. 11 (1980) 233-260.

[8] Chapin F.S. III., Bloom A.J., Field C.B., Waring R.W., Plant responses to multiple environmental factors, BioScience 37 (1987) $49-57$. 
[9] Chapman S.C., Barreto H.J., Using a chlorophyll meter to estimate specific leaf nitrogen of tropical maize during vegetative growth, Agron. J. 89 (1997) 557-562.

[10] Clarkson D.T., Carvajal M., Henzler T., Waterhouse R.N., Smyth A.J., Cooke D.T., Steudle E., Root hydraulic conductance: diurnal aquaporin expression and the effects of nutrient stress, J. Exp. Bot. $51(2000) 61-70$

[11] Coleman M.D., Dickson R.E., Isebrands J.G., Growth and physiology of aspen supplied with different fertilizer addition rates, Physiol. Plant. 103 (1998) 513-526.

[12] Coll L., Messier C., Delagrange S., Berninger F., Growth, allocation and leaf gas exchange of hybrid poplar plants in their establishment phase on previously forested sites: effect of different vegetation management techniques, Ann. For. Sci. 64 (2007) 275-285.

[13] Dong S., Cheng L., Scagel C.F., Fuchigami L.H., Nitrogen mobilization, nitrogen uptake and growth of cuttings obtained from poplar stock plants grown in different $\mathrm{N}$ regimes and sprayed with urea in autumn, Tree Physiol. 24 (2004) 355-359.

[14] Dyckmans J., Flessa H., Partitioning of remobilized $\mathrm{N}$ in young beech (Fagus sylvatica $\mathrm{L}$.) is not affected by elevated $\left[\mathrm{CO}_{2}\right]$, Ann. For. Sci. 62 (2005) 285-288.

[15] Epstein E., Bloom A.J., Mineral nutrition of plants: principles and perspectives, 2nd ed., John Wiley and Sons Inc., NY, 2004.

[16] Evans J.R., Developmental constraints on photosynthesis: effects of light and nutrition, in: Baker N.R. (Ed.), Photosynthesis and the environment, Kluwer, Dordrecht, 1996, pp. 281-304.

[17] Evans J.R., Photosynthesis and nitrogen relationships in leaves of $\mathrm{C}_{3}$ plants, Oecologia 78 (1989) 9-19.

[18] Freeden A.L., Gamon J.A., Field C.B., Responses of photosynthesis and carbohydrate-partitioning to limitations in nitrogen and water availability in field-grown sunflower, Plant Cell Environ. 14 (1991) 963-970.

[19] Gough C.M., Seiler J.R., Maier C.A., Short-term effects of fertilization on loblolly pine (Pinus taeda L.) physiology, Plant Cell Environ. 27 (2004) 876-886.

[20] Haase D.L., Rose R., Vector analysis and its use for interpreting plant nutrient shifts in response to silvicultural treatments, For. Sci. 41 (1995) 54-66.

[21] Hawkins B.J., Burgess D., Mitchell A.K., Growth and nutrient dynamics of western hemlock with conventional or exponential greenhouse fertilization and planting in different fertility conditions, Can. J. For. Res. 35 (2005) 1002-1016.

[22] Hawkins B.J., Kiiskila S.B.R., Henry G., Biomass and nutrient allocation in Douglas-fir and amabalis fir seedlings: influence of growth rate and nutrition, Tree Physiol. 18 (1998) 803-810.

[23] Hechler W.D., Dawson J.O., DeLucia E.H., Stomatal conductance of seedlings of three oak species subjected to nitrogen fertilization and drought treatments, in: McCormick L.H., Gottschalk K.W. (Eds.), Proc. 8th Central Hardwood Forest Conference, USDA Forest Service Gen. Tech. Report NE - 148, 1991, pp. 188-193.

[24] Hensley D.L., McNeil R.E., Sundheim R., Management influences growth of transplanted Magnolia grandiflora, J. Arboric. 14 (1988) 204-207.

[25] Jacobs D.F., Ross-Davis A., Davis A.S., Establishment success of conservation tree plantations in relation to silvicultural practices in Indiana, USA New For. 28 (2004) 23-26.

[26] Jacobs D.F., Salifu K.F., Seifert J.R., Growth and nutritional response of hardwood seedlings to controlled-release fertilization at outplanting, For. Ecol. Manage. 214 (2005) 28-39.
[27] Jose S., Gillespie A.R., Leaf area-productivity relationships among mixed- species hardwood forest communities of the Central Hardwood Region, For. Sci. 43 (1997) 56-64.

[28] Kleiner K.W., Abrams M.D., Schultz J.C., The impact of water and nutrient deficiencies on the growth, gas exchange, and water relations of red oak and chestnut oak, Tree Physiol. 11 (1992) 271-287.

[29] Kozlowski T.T., Soil moisture and absorption of water by tree roots, J. Arboric. 13 (1987) 39-46.

[30] Landis T.D., Mineral nutrition as an index of seedling quality, in: Duryea M.L. (Ed.), Evaluating seedling quality: Principles, procedures, and predictive abilities of major tests, For. Res. Lab., Oregon State Univ., Corvallis, OR, 1985, pp. 29-48.

[31] Landsberg J.J., Physiological ecology of forest production, Academic Press, London, UK, 1986.

[32] Lawlor D.W., Photosynthesis: molecular, physiological and environment processes, 3rd ed. Bios Scientific Publishers, Oxford, UK, 2001.

[33] Luxmoore R.J., Cunningham M., Mann L.K., Tjoelker M.G., Urea fertilization effects of nutrient uptake and growth of Platanus occidentalis during plantation establishment, Trees 7 (1993) 250-257.

[34] McCrady R.L., Jokela E.J., Canopy dynamics, light interception and radiation use efficiency of selected loblolly pine families, For. Sci. 4 (1998) 64-72.

[35] Millard P., Proe M.F., Nitrogen uptake, partitioning and internal cycling in Picea sitchensis (Bong.) Carr. as influenced by nitrogen supply, New Phytol. 125 (1993) 113-119.

[36] Mooney H.A., Gulmon S.L., Environmental and evolutionary constraints of the photosynthetic characteristics of higher plants, in: Solbrig O.T., Jain S., Johjson G.B., Raven P.H. (Eds.), Topics in plant population biology, Columbia University Press, New York, 1979, pp. 316-337.

[37] Murthy R., Dougherty P.M., Zarnoch S.J., Allen H.L., Effects of carbon dioxide, fertilization, and irrigation on the photosynthetic capacity of loblolly pine trees, Tree Physiol. 16 (1996) 537-546.

[38] Nambiar E.K.S., Do nutrients retranslocate from fine roots, Can. J. For. Res. 17 (1987) 913-918.

[39] Nambiar E.K.S., Fife D.N., Nutrient retranslocation in temperate conifers, Tree Physiol. 9 (1991) 185-207.

[40] Osman A.M., Goodman P.J., Cooper J.P., The effects of nitrogen, phosphorus and potassium on rates of growth and photosynthesis of wheat, Photosynthetica 11 (1977) 66-75.

[41] Parelle J., Roudaut J.P., Ducrey M., Light acclimation and photosynthetic response of beech (Fagus sylvatica L.) saplings under artificial shading or natural Mediterranean conditions, Ann. For. Sci. 63 (2006) 257-266.

[42] Pierce L.L., Running S.W., Walker J., Regional-scale relationships of leaf area index to specific leaf area and leaf nitrogen content, Ecol. Appl. 4 (1994) 313-321.

[43] Pugnaire F.I., Chapin F.S. III., Controls over nutrient resorption from leaves of evergreen Mediterranean species, Ecol. 74 (1993) $124-129$.

[44] Radwan M.A., Effect of forest floor on growth and nutrition of Douglas-fir and western hemlock seedlings with and without fertilizer, Can. J. For. Res. 22 (1992) 1222-1229.

[45] Reddy G.B., Reddy K.R., Fate of nitrogen-15 enriched ammonium nitrate applied to corn, Soil Sci. Soc. Am. J. 57 (1993) 111-115.

[46] Royo A., Gil L., Pardos J.A., Effect of water stress conditioning on morphology, physiology and field performance of Pinus halepensis Mill. seedlings, New For. 21 (2001) 127-140. 
[47] Salifu K.F., Jacobs D.F., Characterizing fertility targets and multielement interactions in nursery culture of Quercus rubra seedlings, Ann. For. Sci. 63 (2006) 231-237.

[48] Salifu K.F., Timmer V.R., Nitrogen retranslocation response of young Picea mariana to nitrogen-15 supply, Soil Sci. Soc. Am. J. 67 (2003) 309-317.

[49] Salifu K.F., Timmer V.R., Nutrient retranslocation response of Picea marina seedlings to nitrogen supply, Soil Sci. Soc. Am. J. 65 (2001) 905-913.

[50] Samuelson L.J., Effects of nitrogen on leaf physiology and growth of different families of loblolly and slash pine, New For. 19 (2000) 95-107.

[51] Sheriff D.W., Roles of carbon gain and allocation in growth at different nitrogen nutrition in Eucalyptus camaldulensis and Eucalyptus globulus seedlings, Aust. J. Plant Physiol. 19 (1992) 637-652.
[52] Struve D.K., Joly R.J., Transplanted red oak seedlings mediate transplant shock by reducing leaf surface area and altering carbon allocation, Can. J. For. Res. 22 (1992) 1441-1448.

[53] Taiz L., Zeigler E., Plant Physiology, 3rd ed., Sinauer Associates, Sunderland, Massachusetts, USA, 2002.

[54] Timmer V.R., Interpretation of seedling analysis and visual symptoms, in: van den Driessche R. (Ed.), Mineral nutrition of conifer seedlings, CRC Press, Boca Raton, FL, USA, 1991, pp. 113-114.

[55] Timmer V.R., Armstrong G., Growth and nutrition of containerized Pinus resinosa seedlings at varying moisture regimes, New For. 3 (1989) 171-180.

[56] Van den Berg A.K., Perkins T.D., Evaluation of a portable chlorophyll meter to estimate chlorophyll and nitrogen contents in sugar maple (Acer saccharum March.) leaves, For. Ecol. Manage. 200 (2004) 113-117. 